\title{
Challenges Encountered by Students in the School for Special Needs in Kwara State,
}

\section{Nigeria $^{1}$}

\author{
Bolu-Steve F. N. \\ Olawuyi B. \\ Gbolade, O. P. \\ University of Ilorin, Nigeria University of Ilorin, Nigeria University of Ilorin, Nigeria \\ bolusteve2002@yahoo.com
}

\begin{abstract}
This study was conducted to investigate the challenges of students for the school of special needs in Kwara State. The descriptive survey research design was used by the researchers for the study. The purposive and simple random techniques were used in selecting 200 special needs students in the school. The questionnaire titled "Challenges of the Students in the School For Special Needs Questionnaire" (CSSSNQ) was administered by the researchers with the help of trained assistance to the respondents in order to elicit information from the sampled respondents. The items of the questionnaire were content validated and test re-test method was used to determine the reliability coefficient of 0.79 . The major challenge of these students was their difficulty to relate unimpaired persons. Percentages were used to present the demographic data, while t-test and Analysis of Variance were used to test the four generated hypotheses. There were no significant differences found in the challenges of students of special needs school in Kwara State on the basis of gender, age, religious affiliation and their type of disability. Based on the findings of this study, it was recommended that alternative educational activities should be provided for these exceptional children. Also, the counselors can give social support to these children through counseling.
\end{abstract}

Keywords: Challenges, Special needs, Students, Disability

1 Research paper, Received: 13.04.2015 Accepted: 30.01.2017 


\section{Introduction}

Students with special needs are subject to different challenges due to their disability. Some of these students may have complex individual needs, such challenges may derive from school climate or interaction with people ( Uchemadu, 2013). Akinpelu (2004) and Okeke (2002) noted that there are different types of disability. These include children with hearing impairment, visual impairment, mentally retarded, learning disabled and the gifted children.

The Federal Ministry of Education (1977) instituted Section 8 of the National Policy on Education which provided special education programs for individuals with disabilities. Special education is defined as any educational provision which is designed to cater for students in special needs schools (Olawale, 2000). The labeling of students as "handicapped" has been replaced by broader descriptions of their learning needs. Garuba (2003) noted that students with disability are children who differ significantly from the average to such an extent that provision of special service becomes mandatory for effective learning, social participation and adjustment. In the same vein, Adeyipo (2014) observed that the visually impaired students cannot effectively benefit from the regular classroom arrangements without provision for braille, typewriter, recorded tapes and other intervention programmes. Also, the hearing impaired needs supportive service through sign language. The same is applicable to other categories of students with disability. Ozoji (2005) emphasized that the special education is tailor to the unique need of the learners.

Special Education Review Committee (SERC) (1993) identified the major areas of disability which includes general learning disabilities, emotional and behavioral disturbance, language and communication difficulties disorders, physical and sensory disabilities. Bakare (2000) emphasized that the children with disability are exposed to certain risks in life which are detrimental to their hopes, dreams and future aspirations. As a result of their disability, they 
are compelled to depend on people who often have negative attitude towards them. A person with special needs is someone with limited or restricted function due to their disability. Thus, a person is handicapped when there is any condition or deviation of physical or intellectual ability that inhibits or prevents achievement (Olawale, 2000). Adesina (2001) defined the word "handicap" as descriptive circumstance of a person who is at a disadvantage in exercising his/her physical, mental or emotional ability. According to the World Health Organization (2000), impairment could be referred to as the physical or mental defect. Impairment is a biological condition that reflects anatomic and physiologic dysfunction in a person (Ozoji, 2010). A disability is a measurable impairment or limitation that interferes with a person's ability. Disability, impairment and handicap have been used interchangeably but they do not have the same meaning although they are interconnected. The first Nigerian Federal College for Special Education was established in Oyo State. Since its inception, the college has graduated many students in the various aspects of special education. During this period, elements of special education courses were introduced into the educational curriculum of teachers and in higher institutions of learning (Abang, 2005 and Ogunsanya, 2010). The government has further accelerated proper functioning of special education through the creation of Department of Special Education at the University of Ibadan. In 1980, a similar department was established at the University of Jos. Today, there are about 105 special education schools that are located all over the nation.

\section{Kwara State School For Special Needs, Ilorin}

The school was established in the year 1974 with Ten (10) pioneering students. In 1984, a unit for the mentally retarded was introduced and the initial name of the school was changed to Kwara State School for the Handicapped, this name was later found to be derogative and insultive in terms of discrimination, as such, the name of the school was changed to Kwara State School for Special Needs. Currently, the school has about 450 pupils cutting accross the 
various units. The school comprise of three (3) units namely: the Visual Impairment, Hearing Impairment and Intellectual Disability Units. These units have different levels i.e. elementary and secondary school.

\section{Problems Faced by Students with Disabilities}

The students with disability are confronted with several challenges in life (Bolanle, 2012). Aside from coping with the trauma of a disability, the student may find it difficult to access several facilities while attending school. After graduation, the student might not be employed because of his/her disability. Babin (1982) stated that the fear of the future is one of the basic problems of special needs students. Bancroft (2001) emphasized that Nigerian education is not adequately funded, and this also has a lot of effect on these students. Certain educational materials, facilities and equipment which could have enabled them to learn without difficulty, are costly hence, many parents cannot afford them. Students of special needs school find it difficult to cope with the syllabus and normal teaching methods when compared with their normal counterparts. Lack of adequate specialists and Para-professionals such as the physiotherapists, pathologists, braillists, sign language interpreters, among others constitutes a challenge (Adeyipo, 2014). According to Akinyemi (2004) some common problems faced by special needs students are as follows:

Most of the special needs students usually develop low self-esteem and this can lead to antisocial behaviors like aggressiveness, lack of self-confidence; and feeling of self-defeatism. Johnson and Kenneth (2006) revealed that low self-concept can lead to psychological problems.

Students with disabilities who find themselves in the midst of normal students are often humiliated and are exposed to contempt as the normal ones may call them names in relation to the type of their disability. In addition, the normal student(s) whether in the classroom or 
outside may discriminate against the special needs students thus bringing about the problem of social acceptability among their mates. Sometimes, they are emotionally unbalanced and denied of their basic rights (Anderson, 2004)

Several authorities in the fields of educational have argued that relationships between parents and children determine to some extent the failure or success of students at school. Parents of students with disability who are uneducated may be unconcerned about their children with disability. Lack of affection and love from parents can make the special need child to be emotionally unstable (Farooq, 2012). Most students with disability experience a lot of anxiety. They are always anxious about the future, how they will ultimately sustain themselves in the future. Some of them are anxious about the nature of their deformity (Safree, Yasin, \& Dzulkifli, 2011)

Another problem that may be faced by these special populace is the fact that, due recognition is not accorded to them as real and full member of the society by the general public and this depends on the nature, and severity of the deformity. Abang (2005) explained that these students are seen by the public as nuisance. As such, many of them have developed infeority complex. Coupled with this also, is the issue of lack of necessary and relevant equipment or other types of support services like textbooks in Braille, homemaker services, sign language interpreters, counselors and so on. When these are lacking, the physically challenged student may not be able to benefit fully from the school system.

\section{Statement of Problem}

It was estimated that the total amount of disabled person(s) in Nigeria is about 3 million and at least 71,800 disabled person(s) are from Kwara state alone. In spite of efforts intensified by government, media and non-governmental organizations towards a change of attitude to people with disabilities, much has not been achieved. Onwuegbu (2008) reported that the 
total number of primary and secondary school students' enrolment in Nigeria stood at about 20 million, students with special needs constituted about 2.4million in Nigerian Schools. Ainscow (1990) stated that children with disabilities are often marginalized and are sometimes excluded from the school systems. These students are frustrated when their aspiration and needs cannot be met because of their disability (Crisp, 2002). Ozoji (2005) revealed that the negative attitude of people towards children with disability can be "more disabling than the disability itself. This is one of the major problems faced by children with special needs. Also Eleweke (1999) pointed out that the rehabilitation centers in many parts of the country are not well funded, lack the material and relevant support to make them functional and creative. Over the years, studies on students with disability have been conducted by some researchers. Johnson and Kenneth (2006) investigated at the impact of disability on children's self-concept, Ajobiewe and Adeniran (1999) carried out a research on management of disability in the family and community while Olawale (2000) worked on counseling exceptional children who have challenges. To the best knowledge of the researchers, none of them worked on challenges encountered by students of special needs in Ilorin, Kwara State. Hence, the purpose of this study was to find out the challenges encountered by students of the school for special needs in Ilorin, Kwara state. According to Ojile (2000), students with disability go through a lot of problems.

\section{Research Question}

1. What is the major challenge of students of the school for special needs in Kwara state?

2. Is there any significant difference in the challenges encountered by students of the school for special needs in Ilorin, Kwara State on the basis of gender?

3. Is there any significant difference in the challenges encountered by students of the school for special needs in Ilorin, Kwara State on the basis of religion? 
4. Is there any significant difference in the challenges encountered by students of the school for special needs in Ilorin, Kwara State on the basis of age?

5. Is there any significant difference in the challenges encountered by students of the school for special needs in Ilorin, Kwara State on the basis of their type of disability?

\section{Research Hypothesis}

1. There is no significant difference in the challenges experienced by students of the school for special needs in kwara State on the basis of gender.

2 There is no significant difference in the challenges experienced by students of the school for special needs in kwara State on the basis of religion.

3 There is no significant difference in the problems experienced by students of the school for special needs in kwara State on the basis of age.

4 There is no significant difference in the problems experienced by students of the school for special needs in kwara State on the basis of their type of disability.

\section{Methodology}

\section{Research Design}

The research design adapted for this study is the descriptive survey method. Daramola (1992) described descriptive survey as a systematic description of event in a very factual and accurate manner. This method enables information to be obtained from a representative sample of the population. 


\section{Sample and Sampling Techniques}

The school for special needs Ilorin is the only school in Kwara State as such it was purposively selected for this study. The target population for this study comprised of all the students in the school for special needs in Ilorin. From this population, simple random sampling was used in selecting 200 students who could actually respond to the questionnaire. With the help of the research assistant questions were read to students with visual impairment and their desired options were ticked. Students with intellectual disability were aided by their teachers. These teachers are trained to handle students with intellectual disability. The researchers took permission from the school authority before the questionnaires were administered to the students.

\section{Instrumentation}

The instrument used for this study is titled "Challenges of Students in the School for Special Needs Questionnaire (CSSSNQ)". The questionnaire which was developed by the researchers consisted of two (2) sections; the first section elicited for personal information which includes; age, religion, sex, class, ethnicity and their form of disability. The second part has 15 items which the students were required to respond to on a Four-Point Likert Type Scale of Strongly Agree - 4 Points, Agree -3 Points, Disagree - 2 Points and Strongly Disagree- 1 Point.

The validity of the instrument was established by giving copies of the questionnaire to three (3) experts in the related field. The final draft was done in line with the suggestions of these experts who adjudged the instrument valid and relevant.

In other to ascertain the reliability of the instrument test re-test method was adopted. The test was administered on the same group of respondents who were not part of the study at an interval of four weeks. The two set of scores obtained were correlated using Pearson Product 
Moment Correlation co-efficient and a co-efficient of 0.79 was obtained. The instrument was therefore considered reliable and suitable for the purpose for which it was designed.

\section{Method of Data Analysis}

Frequency count and percentage distribution statistics were used to compute the demographic data of the respondents. The t-test and Analysis of Variance (ANOVA) were used to test the hypotheses at 0.05 alpha level.

\section{Results}

\section{Demographic Data}

The result of data obtained from the respondents personal information was presented in frequency counts and percentages.

Table 1

Distribution of respondents on the basis of gender

\begin{tabular}{lcc}
\hline & $\begin{array}{c}\text { Frequency } \\
(\mathrm{N}=200)\end{array}$ & Percentage \\
\hline Gender & 103 & 51.5 \\
Male & 97 & 48.5 \\
Female & & \\
Religion & 22 & 11.0 \\
African Traditional Religion & 113 & 56.5 \\
Christianity & 65 & 32.5 \\
Islam & & \\
& & \\
Age & 79 & 39.5 \\
$15-18$ years & 97 & 48.5 \\
19 - 22 years & 24 & 12.0 \\
23 years and above & & \\
Type of Disability & & 38.0 \\
Hearing Impairment & 76 & 26.5 \\
Visually Impairment & 53 & 27.5 \\
Physical disability & 55 & 8.0 \\
Intellectual disability (mild) & 16 & \\
\end{tabular}


Table 1 showed that 200 respondents participated in the study out of which $103(51.5 \%)$ were male, $97(48.5 \%)$ of the respondents were female, $22(11 \%)$ of the respondents were of the African Traditional Religion, $113(56.5 \%)$ are Christians, $65(32.5 \%)$ were of Islamic religion. $79(39.5 \%)$ of the respondents were between 15-18 years, $97(48.5 \%)$ were between 19 - 22 years, while $24(12 \%)$ were 23 years and above. Table 1 showed that $76(38 \%)$ of the respondents had hearing impairment problem, 53 (26.5\%) were visually impaired, 55 (27.5\%) physically challenged and $16(8 \%)$ were intellectually challenged. Those with mild intellectual disability are those students that obtained low I.Q scores due to neurological damage. These group of people can achieve minimum competence.

Table 2

Mean and rank order on the challenges encountered by students of school for special needs

\begin{tabular}{|c|l|l|l|}
\hline $\begin{array}{l}\text { Item } \\
\text { No. }\end{array}$ & As far as I am concerned my major challenge is : & Mean & Rank \\
\hline 10 & $\begin{array}{l}\text { that i find it difficult to interact with my other peer group who } \\
\text { are not impaired }\end{array}$ & 2.11 & $1^{\text {st }}$ \\
\hline 14 & lack awareness on vocational opportunities & 2.08 & $2^{\text {nd }}$ \\
\hline 4 & the problem of low self-esteem due to my present condition & 2.04 & $3^{\text {rd }}$ \\
\hline 15 & the feeling of rejection from parents & 2.02 & $4^{\text {th }}$ \\
\hline 9 & the lack of recognition as full members of the society & 1.86 & $5^{\text {th }}$ \\
\hline 7 & the level of high anxiety about the future & 1.86 & $6^{\text {th }}$ \\
\hline 2 & the lack of interest in schooling & 1.84 & $7^{\text {th }}$ \\
\hline 6 & the problem of restricted mobility and coordination & 1.84 & $8^{\text {th }}$ \\
\hline 12 & the lack of attention of the school personnel & 1.82 & $9^{\text {th }}$ \\
\hline 13 & the difficulty I encounter in carrying out my daily chores & 1.82 & $10^{\text {th }}$ \\
\hline 8 & the inadequacy of teaching and learning materials & 1.79 & $11^{\text {th }}$ \\
\hline 3 & $\begin{array}{l}\text { that I find it difficulty in communicating with other impaired } \\
\text { student such as the deaf or mentally retarded }\end{array}$ & 1.76 & $12^{\text {th }}$ \\
\hline 11 & lack of financial assistance & 1.71 & $13^{\text {th }}$ \\
\hline 1 & the Un-conducive learning environment & 1.68 & $14^{\text {th }}$ \\
\hline 5 & that I am unable to properly integrate into the society & 1.62 & $15^{\text {th }}$ \\
\hline
\end{tabular}

Table 2 showed that item 10 ranked 1 st with a mean score of 2.11 and it states that "As far as I am concerned my major challenge is that i find it difficult to interact with my other peers who are not impaired". Ranked 2nd is item 14 with a mean a score of 2.08 , which states that 
"As far as I am concern my major challenge is that I lack awareness on vocational opportunities". Ranked 15 th is item 5 respectively.

\section{Hypotheses Testing}

Hypothesis One: There is no significant difference in the challenges experienced by students of the school for special needs in Ilorin on the basis of gender.

Table 3

Mean, standard deviation and $t$-Value on the problems facing special students in Ilorin on the basis of gender

\begin{tabular}{lccccccc}
\hline Gender & & Mean & SD & df & Cal. t-value & Crit. t-value & p-value \\
\hline Male & 103 & 28.20 & 5.57 & \multirow{2}{*}{198} & 1.18 & 1.96 & .314 \\
& & & & & & & \\
Female & 95 & 27.32 & 4.77 & & & & \\
\hline
\end{tabular}

Table 3 shows a calculated t-value of 1.18 is less than a critical t-value of 1.96 , with corresponding p-value of .314 which is greater than 0.05 alpha level of significant. Since pvalue is greater than 0.05 alpha level, the hypothesis is said to be accepted. Hence, there is no significant difference in the challenges experienced by students of the school for special needs on the basis of gender.

Hypothesis Two: There is no significant difference in the challenges experienced by students of the school for special needs in Ilorin on the basis of religion. 
Table 4

Analysis of variance (ANOVA) showing the difference in the problems facing special students in Ilorin on the basis of religion

\begin{tabular}{lcccccc}
\hline Source & df & SS & $\begin{array}{c}\text { Mean } \\
\text { Square }\end{array}$ & Cal. F-value & Crit. F-value & p-value \\
\hline Between Groups & 2 & 45.952 & 22.97 & 0.84 & 3.00 & .278 \\
& & & & & & \\
$\begin{array}{l}\text { Within Groups } \\
\text { Total }\end{array}$ & 197 & 5416.923 & 27.49 & & & \\
\hline
\end{tabular}

Table 4 shows that the calculated F-value of 0.84 is less than the critical value of 3.00 with corresponding p-value of .278 which is greater than 0.05 alpha level of significance. The hypothesis is upheld since p-value is greater than alpha level. As such, there is no significant difference in the challenges experienced by students of the school for special needs on the basis of religion (i.e Christianity, Islamic \& African traditional religion).

Hypothesis Three: There is no significant difference in the challenges experienced by students of the school for special needs in Ilorin on the basis of age.

Table 5

Analysis of variance (ANOVA) showing the difference in the problems facing special students in Ilorin on the basis of age

\begin{tabular}{lrrcccc}
\hline Source & Df & SS & $\begin{array}{c}\text { Mean } \\
\text { Square }\end{array}$ & Cal. F-value & Crit. F-value & p-value \\
\hline Between Groups & 2 & 22.204 & 11.10 & 0.40 & 3.00 & .534 \\
Within Groups & 197 & 5440.671 & 27.61 & & & \\
Total & 199 & 5462.875 & & & &
\end{tabular}

Table 5 shows the calculated F-value of 0.40 less than the critical value of 3.00 with the corresponding p-value of .534 is higher than 0.05 alpha level of significance. Hence, since the 
p-value is greater than alpha level therefore, the hypothesis is accepted. This indicates that there is no significant difference in the problems experienced by students of the school for special needs in Ilorin on the basis of age (between 15-18 years, 19-22 years \& 23 years and above).

Hypothesis Four: There is no significant difference in the challenges experienced by students of the school for special needs in Ilorin on the basis of their type disability.

Table 6

Analysis of variance (ANOVA) showing the difference in the problems facing special students in Ilorin on the basis of their type of disability

\begin{tabular}{lrrcccl}
\hline Source & df & SS & $\begin{array}{c}\text { Mean } \\
\text { Square }\end{array}$ & Cal. F-value & Crit. F-value & p-value \\
\hline Between Groups & 3 & 23.779 & 7.92 & 0.28 & 2.60 & .432 \\
& & & & & & \\
Within Groups & 196 & 5439.096 & 27.75 & & \\
Total & 199 & 5462.875 & & & \\
\hline
\end{tabular}

Table 6 shows the calculated F-ratio of 0.28 is less than the critical F-ratio of 2.60 with corresponding p-value of .432 greater than 0.05 alpha level of significance. As such the hypothesis is accepted. That is, there is no significant difference in the challenges experienced by students of the school for special needs in Ilorin on the basis of their disability.

\section{Discussion}

This study revealed that the major challenge of students in the school for special needs is the difficulty they experience in their daily interactions with their unimpaired peers. Olawale (2000) noted these students with disability are exposed to discrimination due to their disability. Okoye (2010) opined that one of the basic challenges of students with disabilities is the feeling of loss of self-worth when aspirations are not met. Irrespective of the student's gender, such feelings often lead to inferiority complex which is a common phenomenon 
among the students with disability. Also Akinpelu (2004) is of the opinion that disability obstructs growth and educational progress. This is because students with disability cannot carry out duties and assignments at the normal speed when compared with those who are not challenged.

With the disparity in their religious affiliations, the challenges experienced by these students are still a source of concern. Farooq (2012) explained that despite the rapid increase in the number of organizations serving this community, the problems and training of special needs students remain a serious issue for experts, policy makers and stake holders. In other words, their religious believe has not helped in reducing these problems but rather to cope with such challenges.

The result from this current study revealed that students of different age groups in the school for special needs in Ilorin perceive their challenges the same way. This is in line with the submission of Crisp (2002) that irrespective of age many of the physically challenged students encounter a lot problems in schools and such challenges often lead to frustration. In a study carried out by Farooq (2012) the entire group that participated in the study agreed that there were structural and personal problems experienced by students of the special needs schools and these include negative attitude of the people towards the disabled, lack of assistive devices due to financial challenged.

\section{Conclusion}

There is no significant difference in the problems experienced by students of the school for special needs in Ilorin on the basis of age.

There is no significant difference in the problems experienced by students of the school for special needs in Ilorin on the basis of gender. 
There is no significant difference in the problems experienced by students of the school for special needs in Ilorin on the basis of religion.

There is no significant difference in the problems experienced by students of the school for special needs in Ilorin on the basis of their disability.

\section{Implıcatıon of Findings for Counselors and Educatıonal Psychologist}

Counseling is a helping profession that helps an individual live a balanced, well adjusted, meaningful life. The major goal of counseling profession is problem resolution; as such counselors can help to train students of the school for special needs on the various coping strategy skills. Counselors can also organize Individual and group counseling for these students especially when they are faced with some major challenges.

Counselors can encourage parents of students with disability to seek medical attention rather than conforming to cultural explanations of the illness. The educational psychologist who is concerned with the psychological well-being of the individual within the educational setting will do a lot to help with the self-concept and other related problem.

\section{Recommendations}

The Federal Government should be encouraged to make education free and compulsory for people with special needs. Alternative educational activities should be provided for these exceptional children through inclusive education. Inclusive education is the process by which people with disabilities are placed in a regular school environment to receive instruction with regular students. Professional counselors, educational psychologist and trained special education teachers should be employed because a trained School counselor can understand student's concerns and provide necessary assistance. Early identification of these special 
AJESI - Anadolu Journal of Educational Sciences International, 2017; 7(1): 184-202

needs student's concerns/problems and proper intervention can be achieved through effective inter-personal relationship between the school counselors. 


\section{References}

Abang, B. T., (2005). The exceptional child: Handbook of special education, Jos, Nigeria.

Adesina, S.S. (2001). Disability in Nigeria. A paper presented at kwara State Day of Disabled: Ilorin

Ainscow M and Memmenasha H (1998). Education of children with special needs: Barriers and opportunity in Central and Eastern Europe. Occasional papers on economic and social policy series 67

Akinpelu, O.F. (2004). Managing Handicapped Student in Schools. In A. Idowu (ed.) Guidance and counseling in Education, Ilorin. INDEMAC publishers (NIG.) Ltd.

Akinyemi A.A. (2004). Causes of handicapping condition as perceived by parents in Ife North Local Government, Ipetunmodu, Osun State. An Unpublished B.Ed. Thesis, University of Ilorin.

Ainscow, M. (1990), "Special Needs in the Classroom: The Development of a Teacher Education Resource Pack”. International Journal of Special Education, 5: 13-20.

Anderson, D. W., (2004). Human rights and persons with disabilities in developing nations of Africa. Paper presented at the 4th Annual Lilly Fellows Program National Research Conference, Birmingham, AL.

Anderson G (2004). Hearing impairment, coping strategies, and anxiety sensitivity. Psychol. Med. 10: 35-39. 
Bain, D. (1982). Instructional design for Special Education. Englewood Cliffs, New Jersey: Educational Technology Publications.

Bakere, A.C. (2000). Integration in education: The case of education for the handicapped children in Nigeria. International Journal of Special Education, 7, 225-260.

Bancroft, J. (2001). Support in science for students with special education needs. Science Education Newsletter, 153, 1 - 5.

Crisp, R, (2002). A counselling framework for understanding individual experiences of socially constructed disability. Disability Study. 22: 20-32.

Daramola O.S., (1992). Research Methods and Statistical Analysis in Education. Ado-Ekiti: Petoa Educational Publishers.

Eleweke C. J., (1999). The need for mandatory legislations to enhance services to people with disabilities in Nigeria.Disability \& Society, 14, 227-237.

Fakomogbon A.M., (1998). 'Teachers awareness of resource and services needed for integrating handicapped students in the public schools in Ilorin, Kwara State'. Ilorin Journal of Education 18, 26-35.

Farooq . A. (2012) Problems faced by students with special needs in ordinary Pakistan schools. Journal of quality and Technology Management 8(1), 13-27

Federal Ministry of Education, (2004).National Policy on Education. $\quad$ Lagos, Nigeria: Author.

Ihunnah A. C., (2004). The status of special education in a developing country: Nigeria. Unpublished Doctoral dissertation, Virginia Polytechnic Institute and State University, Blacksburg, VA. 
Ogunsanya A, (2010). Federal College of Education (Special) Oyo State, Nigeria. Retrieved from: www.directory-Nigeria.org/federal-college-of- education special-Oyo, on $\quad$ March, 202012.

Olawale, S.G. (2000), Counselling Exceptional Children. A handbook for Professionals and Parents working with Exceptional Children. Ibadan: HMS publications (Inc.)

Onwuegbu L.O., (2008). The Nigeria culture: Its perception and treatment of the handicapped. Unpublished essays, Federal Advanced Teachers College for Special Education, Oyo State, Nigeria.

Ozoji E.D., (2005). Volunteering for the handicapped: The example of a voluntary association in $\quad$ Nigeria. Vision Magazine, 3(1), 3-5

Okoye O. (2010). Support systems and coping strategies available to physically challenged students in University of Nigeria, Nsukka . Department of Social Work, University of Nigeria, Nsukka, Enugu State, Nigeria. International Research Journals, $\quad$ 1(11) 666-67.

World Health Organization (1980): International Classification of Impairments, Disabilities and Handicaps a Manual of Classification. Relating to Consequences of Disease. Geneva: World Health Organization. 